\title{
Using genetic variation in Aedes aegypti to identify candidate anti-dengue virus genes
}

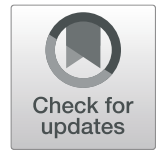

Gerard Terradas $^{1}$ and Elizabeth A. McGraw ${ }^{1,2^{*}}$ (D

\begin{abstract}
Background: Transcriptomic profiling has generated extensive lists of genes that respond to viral infection in mosquitoes. These gene lists contain two types of genes; (1) those that are responsible for the insect's natural antiviral defense mechanisms, including some known innate immunity genes, and (2) genes whose change in expression may occur simply as a result of infection. As genetic modification tools for mosquitoes continue to improve, the opportunities to make refractory insects via allelic replacement or delivery of small RNAs that alter gene expression are expanding. Therefore, the ability to identify which genes in transcriptional profiles may have immune function has increasing value. Arboviruses encounter a range of mosquito tissues and physiologies as they traverse from the midgut to the salivary glands. While the midgut is well-studied as the primary tissue barrier, antiviral genes expressed in the subsequent tissues of the carcass offer additional candidates for second stage intervention in the mosquito body.
\end{abstract}

Methods: Mosquito lines collected recently from field populations exhibit natural genetic variation for dengue virus susceptibility. We sought to use a modified full-sib breeding design to identify mosquito families that varied in their dengue viral load in their bodies post infection.

Results: By delivering virus intrathoracically, we bypassed the midgut and focused on whole body responses in order to evaluate carcass-associated refractoriness. We tested 25 candidate genes selected for their appearance in multiple published transcriptional profiles and were able to identify 12 whose expression varied with susceptibility in the genetic families.

Conclusions: This method, using natural genetic variation, offers a simple means to screen and reduce candidate gene lists prior to carrying out more labor-intensive functional studies. The extracted RNA from the females across the families represents a storable resource that can be used to screen subsequent candidate genes in the future. The aspect of vector competence being assessed could be varied by focusing on different tissues or time points post infection.

Keywords: Genetic variation, Transcriptomics, Aedes, Dengue virus, Innate immunity

\section{Background}

The Aedes aegypti mosquito is the primary vector of dengue virus (DENV) to humans with roughly $40 \%$ of the world's population at risk of infection [1]. The mosquito has been highly successful in colonizing the tropics and subtropics around the globe, recently spreading out of Africa, assisted by climate change and urbanization

\footnotetext{
*Correspondence: eam7@psu.edu

${ }^{1}$ School of Biological Sciences, Monash University, Melbourne, Victoria 3800, Australia

${ }^{2}$ Center for Infectious Disease Dynamics, Department of Entomology, The Huck Institutes of the Life Sciences, W251 Millennium Science Complex, The Pennsylvania State University, University Park, PA 16802, USA
}

[2]. Despite this rapid expansion, there is evidence of local variation in mosquito susceptibility to DENV [3-6] and diversity of the possible mechanisms conferring refractoriness [7-10].

As DENV traverses the body of the mosquito, the capacity for viruses like DENV to interact with mosquito physiology is vast given the range of tissues and cell types encountered during the process of infection [11-13]. Viruses must first infect the mosquito midgut upon the consumption of a viral laden blood meal and then exit into the carcass. In the body, viruses infect a range of tissues including hemolymph, fat body, nerve and muscle

(c) The Author(s). 2019 Open Access This article is distributed under the terms of the Creative Commons Attribution 4.0 International License (http://creativecommons.org/licenses/by/4.0/), which permits unrestricted use, distribution, and 
$[14,15]$. While the model for dengue viral progression is thought to be stepwise; midgut to organs in the carcass to the salivary glands, there is also evidence that virus may also spread to the rest of the body using the trachea [15]. The genetics of the midgut and salivary gland response have been particularly well studied, as they are thought to serve as particular barriers to virus progression $[16,17]$. The carcass however contains the immune organs [18$20]$ and the bulk of the mosquito's tissue mass where arboviruses are known to replicate [16]. Genes acting in the carcass tissues therefore offer potential opportunities to interfere with viral infection.

Several studies have profiled the transcriptional response of Ae. aegypti to DENV at different time points post infection and in a range of insect tissues [12, 13, 21]. These approaches have been instrumental in characterizing the nature of the insect's humoral immune response [22]. In these studies, there can be thousands of genes exhibiting transcriptional change. It is difficult to disentangle whether changes are related to the host antiviral response, the physiological response of the vector to infection or direct modulation of host pathways by the virus. Additionally, while many insect innate immunity pathways have been mapped including both humoral [23-27] and cellular components [28, 29], it is also clear that large numbers of genes outside of these core pathways function in immunity in unknown ways.

Emerging insect genetic tools, including CRISPR-Cas9 [30-32] and microRNA targeting of gene expression [33] offer means for manipulating the protein coding sequence of key genes in the mosquito as well as altering their expression, respectively. These methods offer not only powerful ways to test individual gene function, but also potential applications in vector borne disease control [34]. Regardless of their ongoing development, these approaches are still labor intensive, as screening the thousands of genes responding to viral infection in vectors is impractical. Techniques for first decreasing the number of candidate genes in the workflow are therefore timely. Examination of candidate gene expression in diverse contexts (tissues, timepoints, viruses) as well as more manipulative scenarios using RNAi or siRNA in cell culture or mosquitoes, respectively offer two means.

Here we selected a set of mosquito candidate genes that were common responders to viral infection across a range of transcriptional profile studies. We then tested for associations between their expression and mosquitoes exhibiting genetic variation for DENV load in their body. While the initial quantitative genetic breeding design utilized for differentiating mosquito families was labor intensive, the RNA collected from individuals is a storable resource that can be revisited in the future to test the behavior of additional gene candidates.

\section{Methods}

\section{Mosquito collection and rearing}

Mosquitoes were collected by the Eliminate Dengue team associated with James Cook University from private properties with permission from the residents within and outside the Eliminate Dengue release zone in Greater Cairns, QLD, Australia. Ae. aegypti were identified by morphology and later checked by Ae. aegyptispecific qPCR primer detection [35]. These wildtype mosquitoes were confirmed not to harbor Wolbachia infection by PCR [35]. Mosquitoes were hatched and reared at a density of $\sim 150$ larvae in $30 \times 40 \times 8 \mathrm{~cm}$ trays containing $3 \mathrm{~L}$ of $\mathrm{RO}$ water in controlled conditions of temperature $\left(26 \pm 2{ }^{\circ} \mathrm{C}\right)$, humidity $(\sim 70 \%)$ and photoperiod (12:12, light:dark). Larvae were fed fish food (Tetramin, Melle, Germany). Males and females were sexed after pupation and transferred separately to $30 \times 30 \times 30$ $\mathrm{cm}$ cages to allow eclosion at a density of $\sim 450$ individuals/cage. Adult mosquitoes were kept on a $10 \%$ sucrose water diet. Six to eight day old adult females (P1) were group fed on human volunteers. A modified full sib breeding design was performed as depicted in a previous paper [36] and yielded 25 independent wildtype mosquito families. In brief, parental single pair crosses (male with a virgin female) were set up and those that exhibited sufficient egg production were selected for $F_{1}$ intercrossing and progressed to $F_{2}$. DENV-2 was then injected intrathoracically into 6-7 day old $\mathrm{F}_{2}$ mosquitoes and either tissues (head, ovaries, midgut and rest of the body) or whole mosquitoes were collected at 7 days post infection to evaluate both DENV-2 loads and candidate gene expression.

\section{Constraints of working with a family-based breeding design}

Experiments involving any type of family-based breeding design must contain large numbers of families and individuals per family to obtain sufficient statistical power to detect differences. Mosquito families are easily disqualified from such designs due to poor oviposition or hatch ranges. Despite that, we obtained 25 families showing a wide range of DENV loads, from which only the extremes were progressed for further study. When evaluating traits like viral loads and gene expression, which can vary immensely between time points, synchronizing and controlling the mosquitoes' age is essential. Families were infected over a period of 2 days. Intrathoracic injection also allowed us to deliver the same amount of virus to all individuals in a controlled manner. DENV load at $7 \mathrm{dpi}$ did not vary with respect to whether the mosquitoes had been injected on the first or second day of infections. Only a single survey point (7dpi) was possible given the size of the experiment and the number of samples needed for statistical power. This time point is 
routinely used for vector competence experiments because infections have disseminated [15] and it is close to the average extrinsic incubation period (EIP), or time to appearance of virus in saliva, of wildtype mosquito populations [36, 37]. As intrathoracic viral delivery speeds the process of infection, mosquitoes would likely be in a slightly later stage of DENV infection.

\section{Virus intrathoracic injections}

Intrathoracic injections were used to focus on antiDENV processes that are body wide, rather than midgut focused and to avoid local blood meal associated changes in gene expression. A dengue virus serotype 2 strain (DENV-2, ET300) isolated from human serum collected from patients from East Timor in 2000 was used for intrathoracic injections. Virus was propagated and collected in cell culture as described previously [38]. Briefly, virus was inoculated into C6/36 cells grown in RPMI 1640 (Invitrogen) supplemented with 1 x Glutamax (Invitrogen) and 2\% FBS and buffered with $25 \mathrm{mM}$ HEPES (Sigma-Aldrich). Seven days post inoculation, virus was collected from the supernatant by centrifugation at $3200 \mathrm{~g}$ for $15 \mathrm{~min}$ at $4{ }^{\circ} \mathrm{C}$. Viral stocks were stored at $-80^{\circ} \mathrm{C}$ until further use and titrated using plaque assays. Ae. aegypti females were anesthetized with $\mathrm{CO}_{2}$ and $59 \mathrm{~nL}$ of DENV ( 70 DENV-2 pfu) were injected intrathoracically using a pulled glass capillary with a manual microinjector (Nanoject II, Drummond Sci., Broomall, PA, USA). The concentration was selected from pilot studies to be sure all mosquitoes had high viral loads. Virus stock was diluted to the desired concentration using culture RPMI media. After injection, mosquitoes were maintained under identical initial controlled conditions as per above.

\section{RNA extractions}

In addition to 327 dissected females, 171 whole mosquitoes were collected as individuals (not pools) at 7 days post injection and extracted using TRIzol (Invitrogen, Carlsbad, CA, USA). Mosquito families included from 5 to 15 individuals, that were each dissected for head, midgut, ovary and salivary glands. For families with greater than 15 individuals, the remainder were collected as whole mosquitoes. All were samples homogenized using a TissueLyser II (Qiagen, Hilden, Germany) and stored at $-80^{\circ} \mathrm{C}$ until further use. RNA was extracted following the manufacturer's instructions. RNA yield was quantified using a Nanodrop ${ }^{\mathrm{mm}}$ Lite Spectophotometer (ThermoFisher Scientific, Waltham, MA, USA). RNA samples were stored at $-80^{\circ} \mathrm{C}$. Heads were used initially to survey for viral infection, but whole bodies were preferred for gene expression analyses as they are likely to capture a broader suite of genes involved with the infection response across the diverse tissues.

\section{DENV analysis}

RNA samples were diluted to a concentration of $10 \mathrm{ng} /$ $\mu \mathrm{l}$ prior to DENV qPCR analysis. One-step quantitative RT-PCR (qRT-PCR) to detect DENV loads was performed using TaqMan ${ }^{\circ}$ Fast Virus 1-step Master Mix (Roche Applied Science, Switzerland) in a total volume of $10 \mu \mathrm{l}$ and following manufacturer's instructions on a LightCycler480 (Roche Applied Science, Switzerland). DENV qRT-PCR reactions were performed as described previously [39]. The number of viral copies present in each sample was evaluated using known standards [40]. The used standards ranged from $10^{8}$ to 10 DENV fragment copies. The limit of detection was set at 100 DENV copies as virus. Concentration of DENV in each sample adjusted to DENV copies/ $\mu$ g of total RNA using the standard curve. Standards and samples were run in duplicate.

\section{Candidate selection}

We carried out a literature search in Pubmed [41] using the terms 'dengue virus' AND 'Aedes' AND 'expression' OR 'transcriptional profile' in March of 2017 to identify all transcriptomic studies examining the mosquito genetic response to dengue virus infection $[9,12,13,21$, 42]. The studies commonly involved surveys across a range of time points post infection and in diverse tissues. The candidates we selected for testing satisfied at least one of the following criteria: the gene demonstrated significant change in expression in more than one transcriptomic profile; the gene exhibited significant expression change in a single transcriptome but has been previously unexplored in the literature for a role in DENV control; the gene showed high differential expression at $7 \mathrm{dpi}$, but not at any other surveyed time point. The original source(s) for each candidate gene and direction of expression modulation is shown in Table 1.

\section{Candidate gene expression}

SuperScript $^{\circ}$ III Reverse Transcriptase kit (Invitrogen, Carlsbad, CA, USA) was used to convert RNA to cDNA in all carcass samples. The reaction contained $12.5 \mu \mathrm{l}$ of RNA undiluted template, $1 \mu \mathrm{l}$ of random primers (RP, 125 $\mathrm{ng} / \mu \mathrm{l}), 1 \mu \mathrm{l}$ of deoxynucleotides (dNTPs, $2.5 \mathrm{mM}$ ), dithiothreitol (DTT), 5X buffer and enzyme as per kit instructions, with a total volume of $20 \mu \mathrm{l}$. cDNA synthesis was performed in a C1000 Thermal Cycler (Bio-Rad, Hercules, CA, USA) on the following temperature profile: $5^{\prime}$ at $65^{\circ} \mathrm{C}$ followed by $10^{\prime}$ at $25^{\circ} \mathrm{C}, 50^{\prime}$ at $50^{\circ} \mathrm{C}, 10^{\prime}$ at $75^{\circ} \mathrm{C}$ and kept at $4{ }^{\circ} \mathrm{C}$. Gene expression levels were detected with SYBR ${ }^{\circ}$ Green I Master (Roche Applied Science, Switzerland) using $1.5 \mu \mathrm{l}$ of a 1:5 dilution from the previously synthesized cDNA on a LightCycler480 (Roche Applied Science, Switzerland). Corresponding Ct values were normalized to the housekeeping Ae. aegypti RpS17 
Table 1 Candidate genes tested and their relevance in DENV control

\begin{tabular}{|c|c|c|c|c|c|c|c|}
\hline Accession number & Gene name & $\begin{array}{l}\text { Transcriptomic } \\
\text { study }\end{array}$ & Function & Tissue & Direction & $\begin{array}{l}\text { Differentially } \\
\text { expressed }\end{array}$ & $\begin{array}{l}\text { Interfamily } \\
\text { variation } \\
\end{array}$ \\
\hline AAEL001022 & smp-30/regucalcin & {$[12,21]$} & $\mathrm{Ca}^{2+}$ binding domain & Whole & Down & Yes & - \\
\hline AAEL001156 & CG5280 & {$[12,13]$} & - & Whole & Up & No & Yes \\
\hline AAEL001392 & defa-assoc & {$[11-13,20]$} & Immunity & Whole, Carcass & Down/Up & Yes & - \\
\hline AAEL002413 & sphingomyelin & {$[12]$} & Cellular membrane & Whole & Down & Yes & - \\
\hline AAEL002585 & CLIPA11 & {$[12,42]$} & Serine protease & Whole, MG & Down & No & Yes \\
\hline AAEL003619 & - & {$[12,21]$} & $\mathrm{Na} / \mathrm{Cl}$ transporter & Whole & Down & Yes & - \\
\hline AAEL003787 & Nopo & {$[12]$} & Zinc finger & Whole & Up & Yes & - \\
\hline AAEL004361 & alpha-glucosidase & {$[12]$} & Glycolysis & Whole & Down & Yes & - \\
\hline AAEL004861 & degringolade & {$[12,13]$} & $\begin{array}{l}\text { Peroxisomal integral } \\
\text { protein }\end{array}$ & Whole, Carcass & Up & No & Yes \\
\hline AAEL005064 & CLIPB5 & {$[12,21]$} & Serine protease & Whole & Down & No & Yes \\
\hline AAEL005527 & Nbr/mut-7 & {$[12,13,21]$} & miRNA maturation & Whole, SG & Down & No & Yes \\
\hline AAEL006995 & CG9657 & {$[12,21]$} & - & Whole & Down & No & No \\
\hline AAEL007495 & $\begin{array}{l}\text { phosphoglycerate } \\
\text { mutase }\end{array}$ & {$[12,13,21]$} & Glycolysis & Whole, Carcass, MG & Down & No & No \\
\hline AAEL007845 & Rab5 & - & Receptor & - & - & Yes & - \\
\hline AAEL008013 & Obp83b & {$[12,21]$} & Odorant & Whole & Down & No & Yes \\
\hline AAEL008108 & GB76C & {$[12,13,21]$} & $\begin{array}{l}\text { Transmembrane } \\
\text { signalling }\end{array}$ & Whole, Carcass, SG & Down & Yes & - \\
\hline AAEL009317 & Rab11 & {$[12]$} & $\begin{array}{l}\text { GTPase, cellular } \\
\text { trafficking }\end{array}$ & Whole & Up & No & No \\
\hline AAEL009602 & Gdap 1 & {$[11,12,21]$} & $\begin{array}{l}\text { Mitochondrial } \\
\text { membrane }\end{array}$ & Whole, Midgut & Down & No & No \\
\hline AAEL009770 & SUMOE2 & {$[12]$} & Sumoylation & Whole & Up & Yes & - \\
\hline AAEL011375 & trypsin & {$[12,13,21]$} & Serine protease & Whole, Carcass & Down & Yes & - \\
\hline AAEL011566 & - & {$[11,12,21]$} & Adhesion & Whole, Carcass, MG & Down & Yes & - \\
\hline AAEL011817 & rent1 & {$[12]$} & mRNA decay & Whole & Down & No & Yes \\
\hline AAEL012089 & xport-A & {$[11,12,21]$} & Phototransduction & Whole, Carcass & Down & No & No \\
\hline AAEL013712 & Trypsin 5G1 precursor & {$[11,12,21]$} & Serine protease & Whole, Carcass & Up & No & No \\
\hline AAEL014108 & aquaporin & {$[12,13,21]$} & $\mathrm{H}_{2} \mathrm{O}$ Transporter & Whole, Carcass & Down & Yes & - \\
\hline
\end{tabular}

Accession numbers, gene names, function and patterns of expression across families with high and low DENV loads for the tested genes. All had been previously reported in transcriptomic studies associated with differences in expression in at least two conditions (tissues/timepoints). Tissues of previous reported expression differences are shown. In "Tissue", MG and SG correspond to midgut and salivary glands, respectively. Whether the genes were up or downregulated in those studies can be seen in "Direction", and our reported expression patterns are shown in the column "Differentially expressed" as well as "Interfamily Variation"

gene [43] and expression ratios obtained using the $\Delta \Delta \mathrm{Ct}$ method [44]. Primer sequences for candidate genes can be found in Additional file 1: Table S1.

\section{Statistical analysis}

DENV loads and gene expression data were analyzed using a generalized mixed model with a random factor 'Family' nested with 'disseminated' DENV load, with the latter also set as a fixed factor. Statistics were performed using IBM SPSS Statistics (v23) and graphs created using Prism 7 (GraphPad Software Inc., San Diego, CA, USA).

\section{Results}

\section{DENV load classification}

We performed a modified full sib breeding design on an Australian population of Aedes aegypti to determine the nature of the genetic variation for DENV susceptibility. We assessed the load of DENV serotype 2 in the head tissue of females 7 days post intrathoracic injection of virus (Fig. 1a) for 25 families of mosquitoes. We then selected a range of families representing the extremes in DENV load (4 each) and confirmed that these differences were also seen in whole body measures of DENV load in sisters from the same families (Fig. 1b), which were later used for gene expression analyses. We used a 

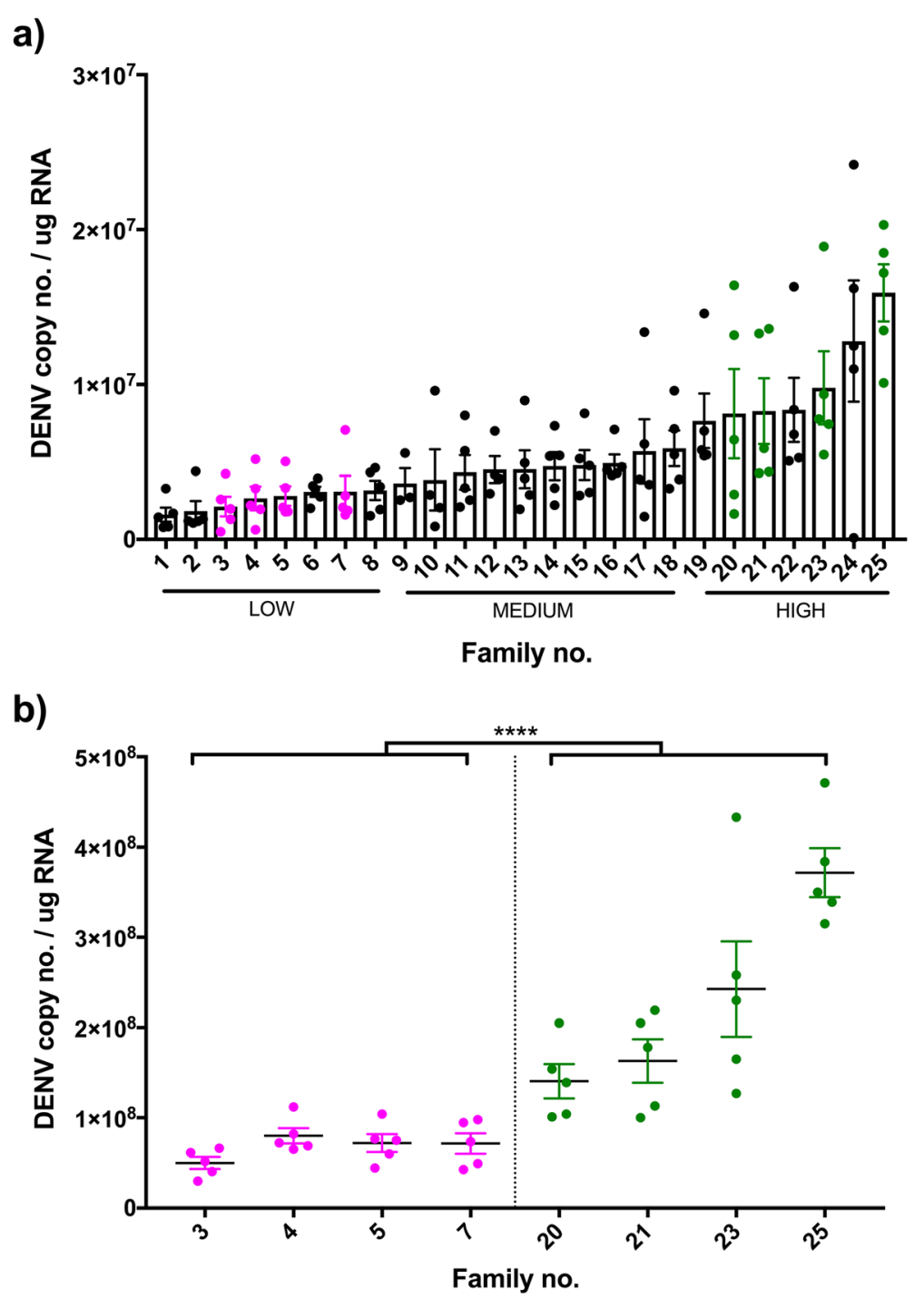

Fig. 1 Disseminated DENV loads. Wildtype DENV-infected families were classified based on head DENV loads; families that were progressed to gene expression analyses are highlighted in pink (Low DENV load) or green (High DENV load) (a). DENV phenotype was later confirmed with whole body load (b). Each dot in the graph depicts a single mosquito. Bars depict family DENV mean and SEM

nested generalized linear model (GLiM) to assess differences in total DENV loads between our extreme families, where 'Family number' was nested within 'DENV load' (High or Low, in heads). We observed a significant effect of 'DENV load' (Wald $=104.08, \mathrm{df}=1, p<0.0001$ ), supporting our designation of families as High or Low. We also observed a 'Family within DENV load' effect (Wald $=81.97, \mathrm{df}=6, \mathrm{p}<0.0001$ ) that relates to the presence of interfamily variation for the trait, especially in the High DENV group.

After demonstrating that DENV load varied between groups, we selected a subset of 4 families each representing the phenotypic extremes of DENV load to test for associations with expression of candidate antiviral genes in whole bodies. Genes tested (Table 1) stem from previous transcriptomic studies, but have yet to be confirmed by further functional studies. A range of genes (roughly half of those tested) representing diverse functional classes did not exhibit patterns of expression across families that would explain differences in DENV load. Other genes, while exhibiting mean expression patterns consistent with DENV control, also exhibited a large amount of variation between families within a phenotypic class and hence could not be interpreted (data available on Figshare). These genes may be highly influenced by environmental or epistatic effects. Neither of these classes of genes would represent good candidates for subsequent genetic modification. Below we present 
the data from genes exhibiting uniformity of response across families within the phenotypic extremes and that differed with respect to DENV load.

\section{Immune genes and signaling}

Host immune responses are one of the main contributors to mosquito pathogen control [22]. Successful bacteria and viruses are able to promote transcription of proteins that suppress key host immune responses, in order for the pathogen to replicate and proliferate freely. Such proteins can be classified in three main ways; molecules that the virus uses as cofactors to replicate (1), molecules involved in cell signaling (2) that in turn activate immune pathways to promote transcription of immune effectors (3).

From the first group, SUMOE2 is a protein with a range of effects on the host, whose high levels have also been linked to increased DENV loads in human cells, as the virus uses sumoylation to tag its NS5 and regulate replication via the suppression of antiviral responses [45]. In our study, the expression of the gene AeSUMOE2 (AAELO09770) had a significant effect of DENV load (Fig. 2a; Wald $=5.34$, $\mathrm{df}=1, p=0.021$ ) and no significant difference was seen between families in each DENV group (Wald $=5.68, \mathrm{df}=6, p=0.46$ ), suggesting that AeSUMOE2 plays a role in DENV control. This is in keeping with the observations from previous transcriptomic studies, where a slight increase in AeSUMOE2 expression was seen in hosts infected with DENV.

We also evaluated the contributions of two proteins that act as signaling molecules, AeGB76C (AAEL008108) and a serine protease (AAEL011375), and one effector, $A A E L 001392$. Little is known about $A e G \beta 76 C$ expression, involved in rhodopsin and signal transduction, but we detected a significant effect based on DENV load (Fig. 2b; Wald $=11.4, \mathrm{df}=1, p=0.001$ ) but not differences within families of each group (Wald $=1.7, \mathrm{df}=6$, $p=0.945)$. Similar effects are seen for AAEL011375, where DENV load group effect was significant (Fig. 2c; Wald $=9.69, \mathrm{df}=1, p=0.002$ ) but no effect of family within DENV load was detected (Wald $=10.17, \mathrm{df}=6$, $p=0.118$ ). Both expression levels correlate with the downregulation seen in previous transcriptomic studies. The expression of AAEL001392, however, does not match the modulation observed in transcriptomic profiles. We observed a significant DENV load effect (Fig. 2d; Wald $=21.42, \mathrm{df}=1, p<0.0001$ ) and no effect of family within DENV load (Wald $=11.22, \mathrm{df}=6, p=$ 0.082 ), but the direction of the main effect is the opposite of that observed in transcriptomic studies, which suggest that its expression is down regulated by the virus, despite other functional studies showing upregulation of the immune effector in response to the viral infection [24].

\section{Apoptosis genes}

Classic signaling immune pathways are not the only responses that the host mount against an incoming pathogen. Different immune pathways usually act synergistically with apoptotic responses to determine infection outcomes $[21,46]$. There have been previous studies that focus on the role of apoptosis-related genes and their relevance to viral control [29, 47, 48], where increased cellular death promotes replication. We evaluated two genes involved in the regulation of apoptosis, AeNopo (AAELO03787) and the senescence marker protein 30 (smp-30/regucalcin, AAEL001022). AeNopo is a zinc finger domain that directly regulates caspase activity and thus its upregulation promotes cell death via activation of pro-apoptotic genes [49]. We observed a significant upregulation of AeNopo in highly infected families (Fig. 3a; Wald $=27.34, \mathrm{df}=1, p<$ 0.0001 ). The variation of the expression in families of the same DENV group was also significant (Wald $=34.76, \mathrm{df}=$ $6, \mathrm{p}<0.0001$ ), suggesting that levels can vary greatly between genotypes. Smp-30 regulates cellular $\mathrm{Ca}^{2+}$ homeostasis and has a role in cellular protection against oxidative stress, which has been linked to DENV infection status [50]. We observed a significant downregulation of smp-30 between DENV groups (Fig. $3 \mathrm{~b}$; Wald $=22.89, \mathrm{df}=$ $1, p<0.0001)$. The variation of the expression in families of the same DENV group was also significant (Wald = 20.37, $\mathrm{df}=6, p<0.002$ ). Both AeNopo and smp-30 data bode well with the transcriptomic patterns seen in previous studies.

\section{Metabolism genes}

Another effect that DENV has on host cells is the modulation of lipid metabolism and its cellular homeostasis. This may be caused by the virus relying on host structures to assemble its own replication machinery, a required modulation of membranes to facilitate viral infection or a mechanism to promote intracellular virion trafficking [51-54]. We analyzed two different molecules involved in metabolism of lipids and sugars that were identified as down regulated in response to a DENVinfected blood meal. In concordance with transcriptomic studies, phosphoglycerate mutase (Pglym, AAEL007495) was observed to be down regulated in highly infected families (Fig. 4a, Wald $=17.47, \mathrm{df}=1, p<0.0001$ ) and so was $\alpha$-glucosidase ( $\alpha$-gluc, AAEL004361) (Fig. 4b, Wald $=38.31, \mathrm{df}=1, \mathrm{p}<0.0001)$. Both genes' expression was also significant when analyzing the variation between families of the same group (Pglym: Wald $=24.27$, $\mathrm{df}=6, \mathrm{p}<0.0001 ; \alpha$-gluc: Wald $=15.13, \mathrm{df}=6, p<0.019)$.

\section{Transporter and adhesion genes}

As mentioned previously, an essential component of the viral success is the attachment of the virion to the cell. After that, membrane fusion can occur and 

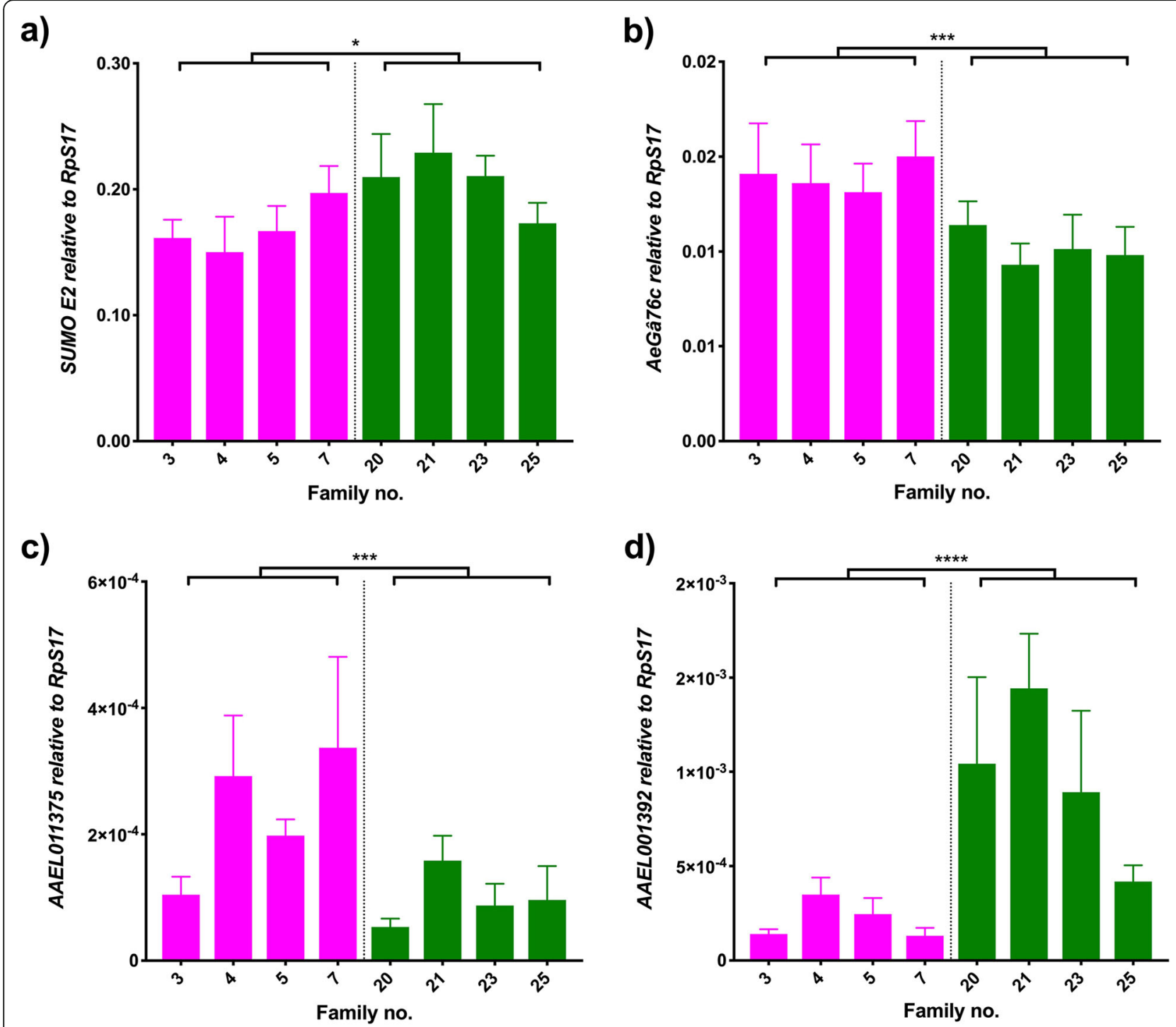

Fig. 2 Immune gene and signalling. Graphs show the expression of (a) SUMOE2, (b) AeGa76C, (c) AAEL011375 and (d) AAEL001392 relative to RpS17 in DENV-infected individuals. Pink bars represent refractory families; green bars represent susceptible families. Bars depict family mean and $\operatorname{SEM}(n=5) .{ }^{*} 0.05<p<0.01,{ }^{* *} 0.001<0.0001,{ }^{* * *} p<0.0001$. The average fold change of refractory/susceptible families is $0.82(\mathbf{a}), 1.37(\mathbf{b}), 2.36$ (c), $0.22(\mathbf{d})$

virus can start replicating inside the cytoplasm. We evaluated differences in expression for a range of intracellular transporters and molecules involved in cellular adhesion. From the latter, an uncharacterized adhesion molecule (AAEL011566) was highly down regulated in both transcriptomic studies on DENV infection and in the effect of bloodmeals in mosquitoes [11]. Our data supports its effects on DENV load, as its expression is down regulated in the high DENV load families (Fig. 5a; Wald $=10.95, \mathrm{df}=1, p<0.0001$ ). Variability among grouped families is also present, as expression differences within families from the same DENV load group are significant (Wald $=15.9, \mathrm{df}=6$, $p=0.014)$. Due to its relevance to viral success, a broad range of molecules involved in adhesion and endocytosis has been characterized in functional studies. Despite no modulation was seen in transcriptomic studies for Rab5 (AAEL007845), an endocytic molecule, it has been previously labelled as a required component for cellular entry of arboviruses [55-57]. We investigated whether differences in expression between low and highly infected families were present at a late infection timepoint. Rab5 expression was significantly up regulated in families belonging to the high DENV load group (Fig. 5b; Wald $=16.34, \mathrm{df}=1$, $p<0.0001)$ and no differences were found among families from the same DENV load group (Wald $=3$, $\mathrm{df}=6, p=0.808$ ). 

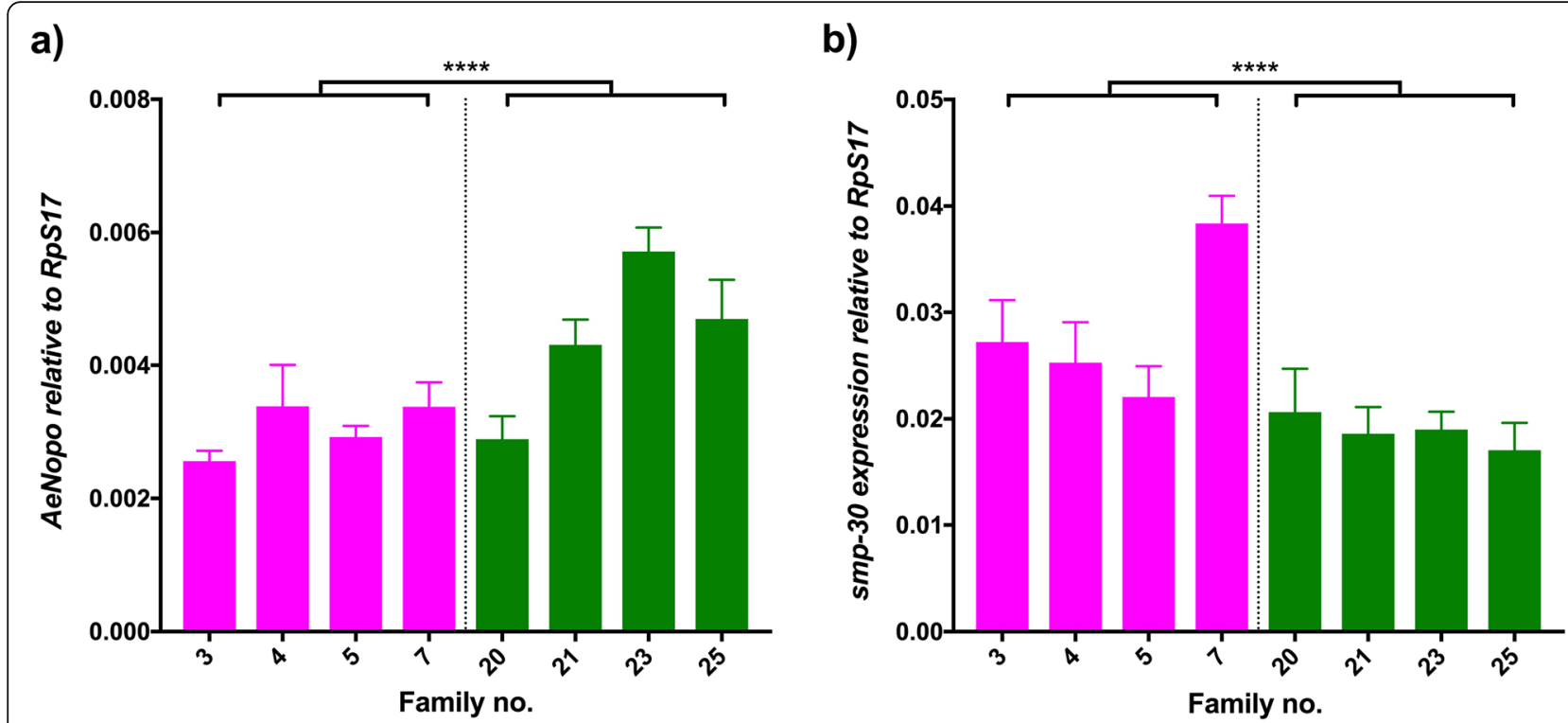

Fig. 3 Apoptosis. Graphs show the expression of (a) AeNopo and (b) smp-30 relative to RpS17 in DENV-infected individuals. Pink bars represent refractory families; green bars represent susceptible families. Bars depict family mean and SEM $(n=5)$. ${ }^{* * *} p<0.0001$. The average fold change of refractory/susceptible families is $0.69(\mathbf{a}), 1.49(\mathbf{b})$

We also analyzed two cellular transporters, aquaporin (AAEL014108) and a putative $\mathrm{Na} / \mathrm{Cl}$-dependent amino acid transporter (AAELO03619). Members of the aquaporin family are transmembrane molecules that transport water and other small solutes in and out of the cell, that may assist with seasonal adaptation and bloodmealinduced diuresis $[58,59]$. Aquaporin was one of the main candidates that arose from different transcriptomic studies [12, 21], showing expression downregulation at all sampled timepoints after arboviral challenge. Similarly, we observed a significant difference in expression for the main effect of DENV load (Fig. 5c; Wald $=29.83$, $\mathrm{df}=1, p<0.0001$ ) but no effect of family within DENV group was present (Wald $=9.46, \mathrm{df}=6, p=0.149$ ).

Downregulation of expression of AAELO03619, an amino acid transporter, may be due to the intracellular
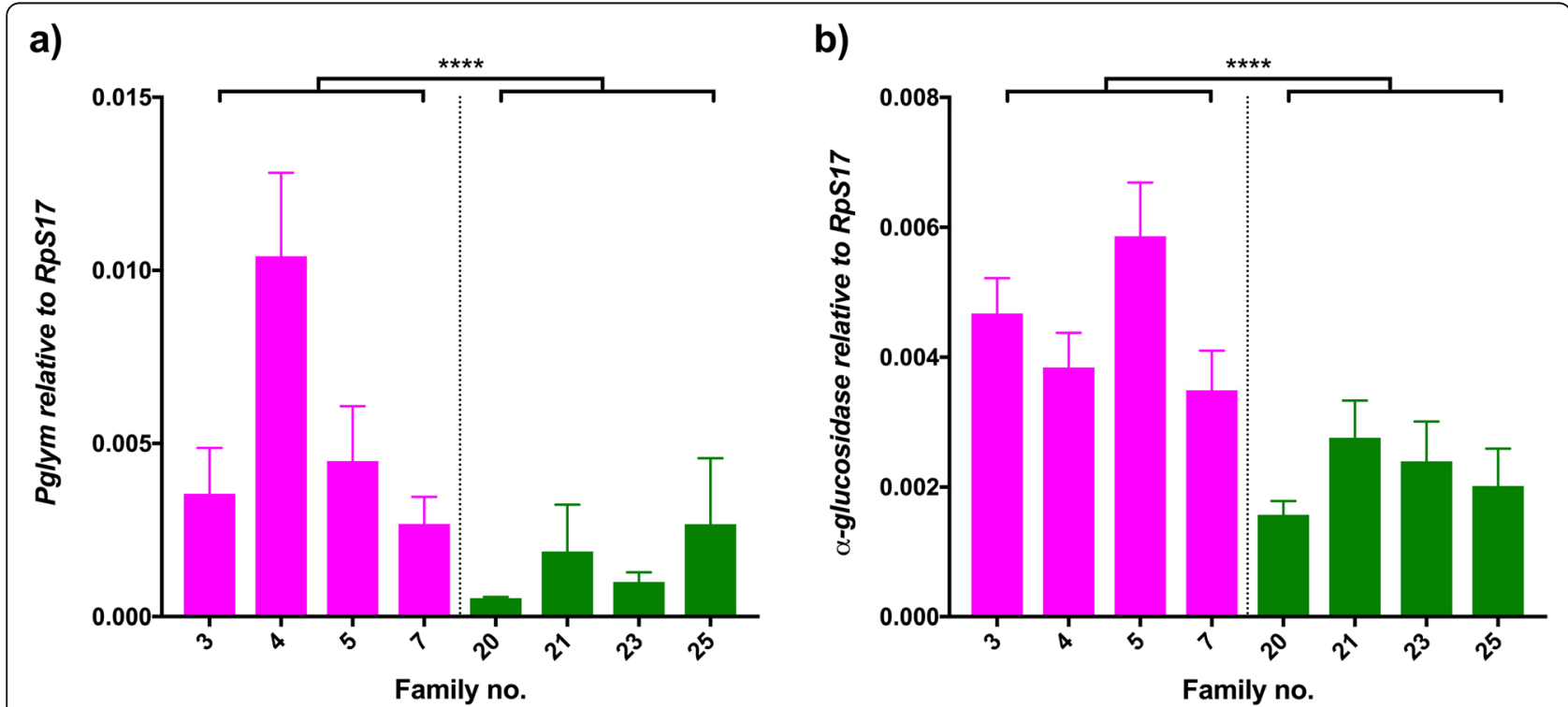

Fig. 4 Metabolism. Graphs show the expression of (a) Pglym and (b) a-glucosidase relative to RpS17 in DENV-infected individuals. Pink bars represent refractory families; green bars represent susceptible families. Bars depict family mean and SEM $(n=5)$. **** $p<0.0001$. The average fold change of refractory/susceptible families is 3.47 (a), 2.04 (b) 

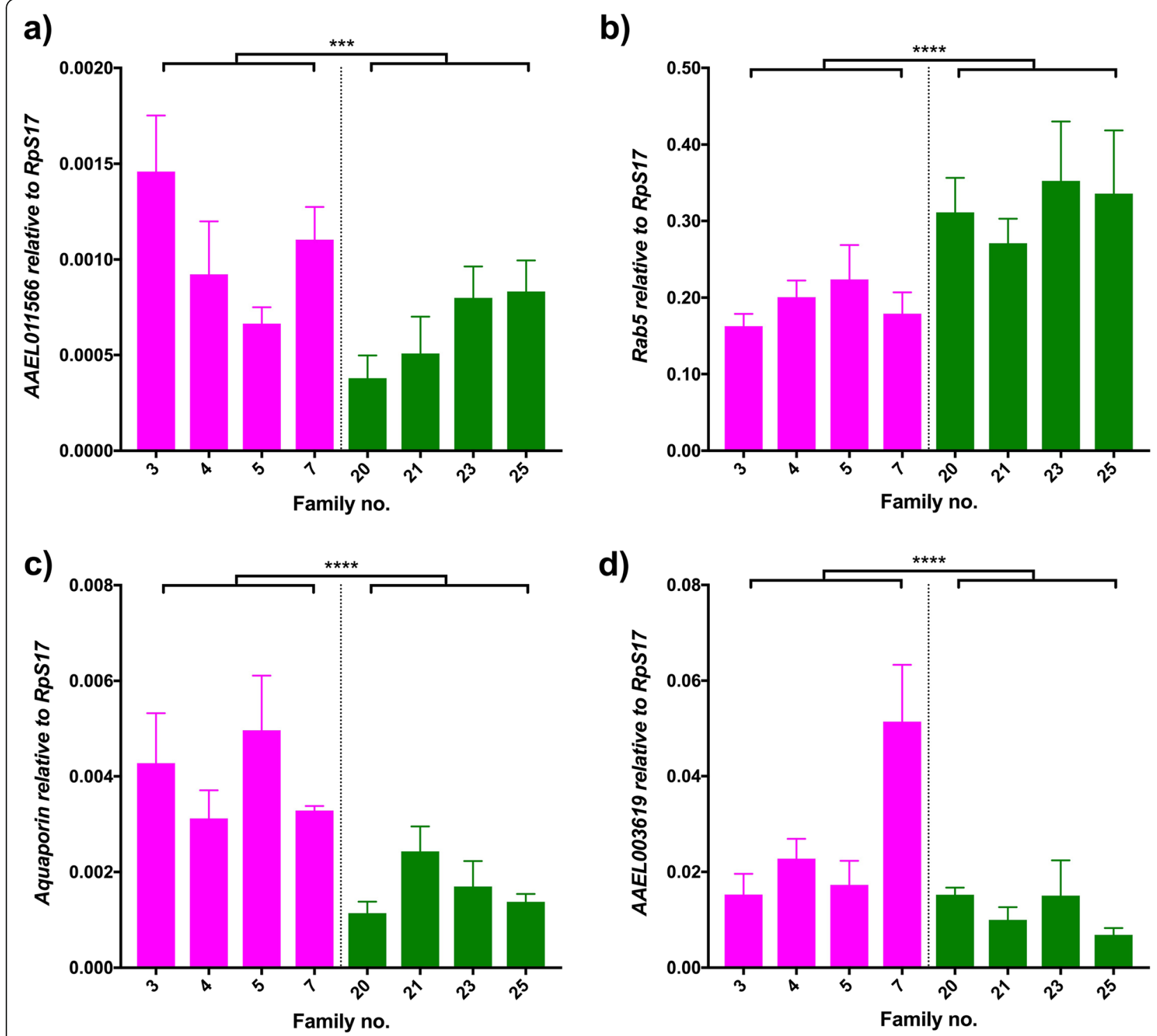

Fig. 5 Adhesion and transport. Graphs show the expression of (a) AAEL011566, (b) Rab5, (c) aquaporin and (d) AAEL003619 relative to RpS17 in DENVinfected individuals. Pink bars represent refractory families; green bars represent susceptible families. Bars depict family mean and SEM $(n=5)$. ${ }^{* * *}$ $0.001<p<0.0001,{ }^{* * * *} p<0.0001$. The average fold change of refractory/susceptible families is 1.64 (a), 2.35 (b), 0.60 (c), 1.10 (d)

amino acid pool being used by the virus to replicate. The effect was significant for DENV load (Fig. 5d; Wald $=16.69, \mathrm{df}=1, \mathrm{p}<0.0001)$ and so was variation within each group, shown by the significance of the effect of family within DENV load (Wald $=33.54, \mathrm{df}=6$, $\mathrm{p}<0.0001$ ).

\section{Discussion}

Transcriptomic studies and other novel approaches that reveal differentially transcribed genes produce lists of candidates that can number in the thousands. When studying the response of a vector to viral infection, some of the gene candidates will be directly involved in viral control, whereas others may simply exhibit change in expression due to the cellular state of the vector. We know that many of the genes changing in response to infection actually do so in response to blood feeding [60, 61] and it is likely that other genes are responding to cellular damage caused by the virus [62]. Here we demonstrate the presence of genetic variation among mosquito families for body cavity DENV load and use this variation to screen candidate virus responder genes for those with possible anti/proviral activity.

We used this natural genetic variation in a mosquito population to specifically test whether candidate genes from previous transcriptomic studies may underpin differences in viral control in the vector. We intentionally focused on genes that had not been explored experimentally 
beyond transcriptional profiling. While we report genes that had distinct RNA expression profiles between families differing in DENV loads, genes that proved unimportant in our study could still play a role in viral control posttranscriptionally. By mapping the expression of candidate genes across families with extremes in vector competence, we were able to identify 12 out of 25 genes whose expression correlates with viral control in our families. These genes corresponded to three clusters of functional classes involved in viral control: immunity, adhesion and intracellular transport and metabolism, reaffirming the importance of these three components to overall infection outcomes.

\section{Immunity}

DENV actively modulates host cellular processes to establish infection and propagate $[63,64]$. The host in turn responds with a range of known antiviral effects, mostly via activation of the innate immune system $[24,26,65]$. Previously, Toll activity has been shown to be required for DENV control in mosquitoes [24] and increased early antiviral protection can be observed in individuals with higher basal activation levels of the pathway [9]. Interestingly, transcriptomic studies demonstrate that a protein likely to be associated to one of the pathway's effector genes, defensin, is routinely down regulated in response to DENV infection [12, 21]. Our results, however, show an upregulation of the gene's expression in families with high DENV loads. This discrepancy may be due to differences in mosquito genotypes, sample time post infection or other factors that vary across studies. Expression of immune effectors varies highly depending on the time post infection $[46,66]$.

The genes SUMOE2 (Fig. 2a), AeNopo and smp-30 (Fig. 3) are thought to be involved in modification processes and apoptotic responses. The former plays a role in sumoylation, a process that stabilizes non-structural DENV proteins for proper replication [45] as well as modification of host proteins [67, 68]. The latter two genes are involved in apoptosis, a cellular death process that promotes DENV replication [47, 69]. AeNopo (Fig.3a) has been shown to drive an interferon-mediated cell death process in Drosophila [49], whose upregulation correlates with higher DENV replication [29]. Increased expression of both SUMOE2 and AeNopo benefit DENV replication and therefore it bodes well with them being highly present in those families with higher infections. The opposite trend is seen for smp-30 (Fig.3b) due to its involvement in oxidative stress protection, down regulated in highly infected individuals.

In addition to modulating host responses, DENV also must hijack host machinery to replicate efficiently $[64,70]$, but we did not find any difference in expression for genes involved in transcription such as the Aedes mut-7 homolog or rent1. Both of these genes are involved in splicing complexes and RNA processing and control [71, 72].

\section{Adhesion and intracellular transport}

In our study, we revealed the differential expression of a variety of adhesion molecules and intracellular transporters that DENV may utilize for entry and replication [73, 74]. Rab5, which has already been shown as required for flavivirus cell entry in humans [55], encodes a protein involved in vesicle formation and regulation of intracellular trafficking. We detected an increase in Rab5 expression in families that harbor greater DENV loads, suggesting it may play a similar role for DENV entry in insects. Studies based on other vector-borne pathogens, including chikungunya and Venezuelan Equine Encephalitis viruses, have demonstrated the role of Rab5 in promoting viral infection [56, 57].

The aquaporin gene is a member of a large family of transporters of water, with known roles in mitigating desiccation [75] and managing bloodmeal-induced diuresis [59]. The expression of aquaporin is commonly down regulated in a range of transcriptomic studies of host responses to DENV, Yellow Fever and West Nile viruses [12, 21]. Similar to transcriptomic studies, we find that it is lowly expressed in families with high DENV loads. However, the exact role of water transporters in blood-sucking insects and how they affect viral replication is still unknown. In Drosophila, aquaporin is primarily expressed in the carcass of the insect [76]. We hypothesize that if the expression pattern is similar in Ae. aegypti, downregulation of aquaporin may promote viral replication by altering the cellular water composition and osmosis of the body cavity.

\section{Metabolism}

DENV uses host receptors and intracellular transporters to achieve infection, but it also relies on lipid rafts and modulation of the cell membrane composition to match that of the viral membrane and therefore facilitate viral entry to host cells $[54,77]$. Our approach detected differential expression for genes involved in metabolism of lipids and sugars and possibly in the redistribution of such host resources. Among these metabolic genes, we detected the downregulation of $\alpha$-glucosidase and Pglym in highly infected families. Studies suggest that $\alpha$ glucosidase is proviral in humans [78, 79] and, as such, the downregulation of its expression is likely a hostinduced anti-viral response. The downregulation detected for Pglym expression may not be due to its antiviral activity, but its position in the glycolysis pathway. Other genes involved on the breakdown of glucose have been reported to be key for viral control, such as aldolase [80]. However, in the same study, Pglym did not 
Table 2 Differentially expressed genes relevant for DENV control

\begin{tabular}{llll}
\hline Accession number & Gene name & Function & Direction of regulation \\
\hline AAEL001022 & smp-30/regucalcin & Senescence marker protein, Ca ${ }^{2+}$ binding domain & Down \\
AAEL001392 & defensin A-assoc & Immunity (TOLL, Imd) & Down/Up \\
AAEL002413 & sphingomyelin & Component of cellular membranes, reshuffling of which is important for virus intake & Down \\
AAEL003619 & - & Putative Na/Cl transporter & Down \\
AAEL003787 & Nopo & Zinc finger, ubiquitination & Up \\
AAEL004361 & alpha-glucosidase & Molecule that mediates glycolysis, essential for virus replication & Down \\
AAEL007845 & Rab5 & Involved in endocytic trafficking of DENV & - \\
AAEL008108 & GB76C & Transmembrane signalling molecule, GTPase activity & Down \\
AAEL009770 & SUMOE2 & Involved in sumoylation, process that stabilizes NS5 for replication & Up \\
AAEL011375 & trypsin & Serine protease; effects of this kind of proteins are well described in the midgut & Down \\
AAEL011566 & - & Putative adhesion molecule & Down \\
AAEL014108 & aquaporin & Water transporter & Down
\end{tabular}

This summary table shows accession numbers, gene names, function and patterns of expression across families for those genes likely involved in DENV control

show antiviral properties. The modulation of metabolic genes may be caused by DENV-mediated redirection of resources inside the host [54]. Despite the importance of metabolic pathways to viral replication, other genes involved in metabolism were also found to be irrelevant for viral control, such as sphingomyelin phosphodiesterase (SMase). SMase is a gene that specifically degrades sphingomyelin (SM), but also acts in response to cellular stresses through production of ceramide, which is linked to DENV infection responses [54]. This suggests that SMase may be acting early in infection, altering the cell outer membrane to produce a more curved membrane that favors DENV infection [81, 82]. However, we would not detect modulation of SMase given the late timepoint post infection we surveyed if SMase was not also directly affecting viral replication.

\section{Caveats}

The design of our study presents some caveats that may limit its interpretation. The experimental conditions differ across the transcriptomic studies we surveyed and from the conditions in our study. Since some host responses are highly plastic, comparisons across different collection points may not be valid. Due to the destructive nature of the collections, the scale of breeding designs, and the sample size needed to achieve statistical power within and between families, only one time point (7dpi) could be assessed. Our results, while finding genes whose expression correlates with expression, do not speak to the excluded genes that could be relevant at different time points or in other tissues, etc. Additionally, we bypassed the midgut by injecting DENV-2 intrathoracically, which does not mimic a natural infection. Generally, the midgut is a physical host barrier that increases variability in susceptibility to the virus, as the ability to confront the infection will vary from mosquito to mosquito, even within the same viral-mosquito strain combination. For the purpose of our study, intrathoracic injections allowed us to focus solely in the variability of infection mediated by the carcass. This method also allowed control of the amount of virus delivered into each mosquito. Injection can cause changes in gene expression due to trauma itself, but any expression differences observed in our experiments cannot be due to trauma since all individuals received the same treatment. Regardless, these elicited responses tend to be short lived [12] and hence are likely to have returned to basal levels by sampling point.

\section{Conclusions}

In conclusion, we found that natural genetic variation in vector competence within a single line of mosquitoes can be used to test for expression of gene candidates that vary with respect to viral control. This approach may offer a stepping stone from long lists of gene candidates produced in transcriptomic and other genomewide expression studies prior to beginning more laborintensive functional studies. It may also help to identify candidate genes not previously identified as antiviral. In this study, we have generated a list of 12 candidate genes that should be further examined as potential targets of gene modification to produce DENV-refractory mosquitoes (Table 2).

\section{Additional file}

Additional file 1: Primer sequences used to test the expression of the different gene candidates. (PDF $47 \mathrm{~kb}$ )

Abbreviations

DENV: Dengue virus; Dpi: Days post infection; ElP: Extrinsic incubation period 


\section{Acknowledgements}

The authors would like to acknowledge Emily Kerton for assistance with mosquito breeding.

\section{Authors' contributions}

The experiments were designed by GT and EAM. The laboratory work was carried out by GT. Data analysis was performed by GT and EAM. The manuscript was written by GT and EAM. Both authors read and approved the manuscript.

\section{Funding}

The research was supported by an NHMRC grant (APP1020607) to EAM. The funders had no role in the design of the study, collection, analysis and interpretation of the data, or in writing the manuscript.

\section{Availability of data and materials}

The datasets supporting the conclusions of the article are available in Figshare DOI https://doi.org/10.4225/03/5955dbeb34336

\section{Ethics approval and consent to participate}

The ET300 DENV strain was received from researchers associated to University of Queensland (UQ) and Queensland Health, Australia. Patient data were anonymized by QH while IRB approval was obtained from UQ. Ethical approval for the research was obtained via The Monash University Human Research Ethics Committee (permit CF11/0766-2011000387). Adult human volunteer blood feeders agreed upon written informed consent prior to the study. No data were collected on these individuals.

\section{Consent for publication}

Not applicable.

\section{Competing interests}

The authors declare that they have no competing interests.

Received: 18 November 2018 Accepted: 23 June 2019 Published online: 04 July 2019

\section{References}

1. Bhatt S, Gething PW, Brady OJ, Messina JP, Farlow AW, Moyes CL, Drake JM, Brownstein JS, Hoen AG, Sankoh O, et al. The global distribution and burden of dengue. Nature. 2013;496(7446):504-7.

2. Kraemer MU, Sinka ME, Duda KA, Mylne AQ, Shearer FM, Barker CM, Moore CG, Carvalho RG, Coelho GE, Van Bortel W, et al. The global distribution of the arbovirus vectors Aedes aegypti and Ae. albopictus. eLife. 2015;4:e08347.

3. Diallo M, Ba Y, Faye O, Soumare ML, Dia I, Sall AA. Vector competence of Aedes aegypti populations from Senegal for sylvatic and epidemic dengue 2 virus isolated in West Africa. Trans Royal Soc Trop Med Hyg. 2008;102(5): 493-8.

4. Bennett KE, Olson KE, Munoz Mde L, Fernandez-Salas I, Farfan-Ale JA, Higgs S, Black WC, Beaty BJ. Variation in vector competence for dengue 2 virus among 24 collections of Aedes aegypti from Mexico and the United States. Am J Trop Med Hyg. 2002;67(1):85-92.

5. Ye YH, Ng TS, Frentiu FD, Walker T, van den Hurk AF, O'Neill SL, Beebe NW, McGraw EA. Comparative susceptibility of mosquito populations in North Queensland, Australia to oral infection with dengue virus. Am J Trop Med Hyg. 2014;90(3):422-30.

6. Whitehorn J, Kien DT, Nguyen NM, Nguyen HL, Kyrylos PP, Carrington LB, Tran CN, Quyen NT, Thi LV, Le Thi D, et al. Comparative susceptibility of Aedes albopictus and Aedes aegypti to dengue virus infection after feeding on blood of viremic humans: implications for public health. J Infect Dis. 2015;212(8):1182-90

7. Bosio CF, Fulton RE, Salasek ML, Beaty BJ, Black WC. Quantitative trait loci that control vector competence for dengue-2 virus in the mosquito Aedes aegypti. Genetics. 2000;156:687-98.

8. Carvalho-Leandro D, Ayres CF, Guedes DR, Suesdek L, Melo-Santos MA, Oliveira CF, Cordeiro MT, Regis LN, Marques ET, Gil LH, et al. Immune transcript variations among Aedes aegypti populations with distinct susceptibility to dengue virus serotype 2. Acta Trop. 2012;124(2):113-9.

9. Sim S, Jupatanakul N, Ramirez JL, Kang S, Romero-Vivas CM, Mohammed H, Dimopoulos G. Transcriptomic profiling of diverse Aedes aegypti strains reveals increased basal-level immune activation in dengue virus-refractory populations and identifies novel virus-vector molecular interactions. PLoS Negl Trop Dis. 2013;7(7):e2295.

10. Terradas G, Allen SL, Chenoweth SF, McGraw EA. Family level variation in Wolbachia-mediated dengue virus blocking in Aedes aegypti. Parasit Vectors. 2017;10(1):622.

11. Dissanayake SN, Ribeiro JM, Wang MH, Dunn WA, Yan G, James AA, Marinotti O. aeGEPUCl: a database of gene expression in the dengue vector mosquito, Aedes aegypti. BMC Res Notes. 2010;3:248.

12. Colpitts TM, Cox J, Vanlandingham DL, Feitosa FM, Cheng G, Kurscheid S, Wang P, Krishnan MN, Higgs S, Fikrig E. Alterations in the Aedes aegypti transcriptome during infection with West Nile, dengue and yellow fever viruses. PLoS Pathog. 2011;7(9):e1002189.

13. Bonizzoni M, Dunn WA, Campbell CL, Olson KE, Marinotti O, James AA. Complex modulation of the Aedes aegypti transcriptome in response to dengue virus infection. PLoS One. 2012;7(11):e50512.

14. Girard YA, Klingler KA, Higgs S. West Nile virus dissemination and tissue tropisms in orally infected Culex pipiens quinquefasciatus. Vector Borne Zoonotic Dis. 2004;4(2):109-22.

15. Salazar Ml, Richardson JH, Sanchez-Vargas I, Olson KE, Beaty BJ. Dengue virus type 2: replication and tropisms in orally infected Aedes aegypti mosquitoes. BMC Microbiol. 2007;7:9

16. Franz AW, Kantor AM, Passarelli AL, Clem RJ. Tissue barriers to arbovirus infection in mosquitoes. Viruses. 2015;7(7):3741-67.

17. Black WC, Bennett KE, Gorrochótegui-Escalante N, Barillas-Mury CV, Fernandez-Salas I, Muñoz ML, Farfán-Alé JA, Olson KE, Beaty BJ. Flavivirus susceptibility in Aedes aegypti. Arch Med Res. 2002;33:379-88.

18. Christensen BM, Li J, Chen CC, Nappi AJ. Melanization immune responses in mosquito vectors. Trends Parasitol. 2005;21(4):192-9.

19. Blair CD, Olson KE. Mosquito immune responses to arbovirus infections. Curr Opin Insect Sci. 2014:3:22-9.

20. Kumar A, Srivastava P, Sirisena P, Dubey SK, Kumar R, Shrinet J, Sunil S. Mosquito innate immunity. Insects. 2018;9(3):95.

21. Behura SK, Gomez-Machorro C, Harker BW, deBruyn B, Lovin DD, Hemme RR, Mori A, Romero-Severson J, Severson DW. Global cross-talk of genes of the mosquito Aedes aegypti in response to dengue virus infection. PLoS Negl Trop Dis. 2011;5(11):e1385.

22. Sim S, Jupatanakul N, Dimopoulos G. Mosquito immunity against arboviruses. Viruses. 2014;6(11):4479-504.

23. Dostert C, Jouanguy E, Irving P, Troxler L, Galiana-Arnoux D, Hetru C, Hoffmann JA, Imler JL. The Jak-STAT signaling pathway is required but not sufficient for the antiviral response of Drosophila. Nature Immunol. 2005;6(9): 946-53.

24. Xi Z, Ramirez JL, Dimopoulos G. The Aedes aegypti toll pathway controls dengue virus infection. PLoS Pathog. 2008;4(7):1-12.

25. De Gregorio E, Spellman PT, Tzou P, Rubin GM, Lemaitre B. The toll and Imd pathways are the major regulators of the immune response in Drosophila. EMBO J. 2002;21(11):2568-79.

26. Souza-Neto JA, Sim S, Dimopoulos G. An evolutionary conserved function of the JAK-STAT pathway in anti-dengue defense. Proc Natl Acad Sci U S A. 2009;106(42):17841-6.

27. Blair CD. Mosquito RNAi is the major innate immune pathway controlling arbovirus infection and transmission. Future Microbiol. 2011; 6(3):265-77.

28. Shelly S, Lukinova N, Bambina S, Berman A, Cherry S. Autophagy is an essential component of Drosophila immunity against vesicular stomatitis virus. Immunity. 2009;30(4):588-98.

29. Eng MW, van Zuylen MN, Severson DW. Apoptosis-related genes control autophagy and influence DENV-2 infection in the mosquito vector, Aedes aegypti. Insect Biochem Mol Biol. 2016;76:70-83.

30. Gantz VM, Jasinskiene N, Tatarenkova O, Fazekas A, Macias VM, Bier E, James AA. Highly efficient Cas9-mediated gene drive for population modification of the malaria vector mosquito Anopheles stephensi. Proc Natl Acad Sci U S A. 2015;112(49):E6736-43.

31. Li M, Bui M, Yang T, Bowman CS, White BJ, Akbari OS. Germline Cas9 expression yields highly efficient genome engineering in a major worldwide disease vector, Aedes aegypti. Proc Natl Acad Sci U S A. 2017;114(49): E10540-9.

32. Chaverra-Rodriguez D, Macias VM, Hughes GL, Pujhari S, Suzuki Y, Peterson DR, Kim D, McKeand S, Rasgon JL. Targeted delivery of CRISPR-Cas9 ribonucleoprotein into arthropod ovaries for heritable germline gene editing. Nat Commun. 2018;9(1):3008. 
33. Yen P-S, James A, Li J-C, Chen C-H, Failloux A-B. Synthetic miRNAs induce dual arboviral-resistance phenotypes in the vector mosquito Aedes aegypti. Commun Biol. 2018;1(1):11

34. Champer J, Buchman A, Akbari OS. Cheating evolution: engineering gene drives to manipulate the fate of wild populations. Nat Rev Genet. 2016;17(3): 146-59.

35. Hoffmann AA, Montgomery BL, Popovici J, Iturbe-Ormaetxe I, Johnson PH, Muzzi F, Greenfield M, Durkan M, Leong YS, Dong Y, et al. Successful establishment of Wolbachia in Aedes populations to suppress dengue transmission. Nature. 2011:476(7361):454-7.

36. Ye YH, Chenoweth SF, Carrasco AM, Allen SL, Frentiu FD, van den Hurk AF, Beebe NW, McGraw EA. Evolutionary potential of the extrinsic incubation period of dengue virus in Aedes aegypti. Evolution. 2016;70(11):2459-69.

37. Tjaden NB, Thomas SM, Fischer D, Beierkuhnlein C. Extrinsic incubation period of dengue: knowledge, backlog, and applications of temperature dependence. PLoS Negl Trop Dis. 2013;7(6):e2207.

38. Frentiu FD, Robinson J, Young PR, McGraw EA, O'Neill SL. Wolbachiamediated resistance to dengue virus infection and death at the cellular level. PLoS One. 2010;5(10):e13398.

39. Terradas G, Joubert DA, McGraw EA. The RNAi pathway plays a small part in Wolbachia-mediated blocking of dengue virus in mosquito cells. Sci Rep. 2017;7:43847

40. Moreira LA, Iturbe-Ormaetxe I, Jeffery JA, Lu G, Pyke AT, Hedges LM, Rocha BC, Hall-Mendelin S, Day A, Riegler M, et al. A Wolbachia symbiont in Aedes aegypti limits infection with dengue, chikungunya, and Plasmodium. Cell. 2009;139(7):1268-78.

41. PubMed: PubMed. Bethesda: National Library of Medicine (US); 1946

42. Zou Z, Souza-Neto J, Xi Z, Kokoza V, Shin SW, Dimopoulos G, Raikhel A. Transcriptome analysis of Aedes aegypti transgenic mosquitoes with altered immunity. PLoS Pathog. 2011;7(11):e1002394.

43. Cook PE, Hugo LE, Iturbe-Ormaetxe I, Williams CR, Chenoweth SF, Ritchie SA, Ryan PA, Kay BH, Blows MW, O'Neill SL. The use of transcriptional profiles to predict adult mosquito age under field conditions. Proc Natl Acad Sci U S A. 2006:103(48):18060-5.

44. Livak KJ, Schmittgen TD. Analysis of relative gene expression data using real-time quantitative PCR and the 2(-Delta Delta C(T)) method. Methods. 2001;25(4):402-8

45. Su Cl, Tseng $\mathrm{CH}$, Yu CY, Lai MM. SUMO modification stabilizes dengue virus nonstructural protein 5 to support virus replication. J Virol. 2016; 90(9):4308-19.

46. $\operatorname{Sim} \mathrm{S}$, Dimopoulos G. Dengue virus inhibits immune responses in Aedes aegypti cells. PLoS One. 2010;5(5):e10678.

47. Ocampo CB, Caicedo PA, Jaramillo G, Ursic Bedoya R, Baron O, Serrato IM, Cooper DM, Lowenberger C. Differential expression of apoptosis related genes in selected strains of Aedes aegypti with different susceptibilities to dengue virus. PLoS One. 2013;8(4):e61187

48. Wang H, Gort T, Boyle DL, Clem RJ. Effects of manipulating apoptosis on Sindbis virus infection of Aedes aegypti mosquitoes. J Virol. 2012;86(12): 6546-54.

49. Ma X, Huang J, Yang L, Yang Y, Li W, Xue L. NOPO modulates Egr-induced JNK-independent cell death in Drosophila. Cell Res. 2012;22(2):425-31.

50. Chen TH, Lo YP, Yang CF, Chen WJ. Additive protection by antioxidant and apoptosis-inhibiting effects on mosquito cells with dengue 2 virus infection. PLoS Negl Trop Dis. 2012;6(4):e1613.

51. Jackson WT, Giddings TH Jr, Taylor MP, Mulinyawe S, Rabinovitch M, Kopito RR, Kirkegaard K. Subversion of cellular autophagosomal machinery by RNA viruses. PLoS Biol. 2005:3(5):e156.

52. Gillespie LK, Hoenen A, Morgan G, Mackenzie JM. The endoplasmic reticulum provides the membrane platform for biogenesis of the flavivirus replication complex. J Virol. 2010;84(20):10438-47.

53. Diaz A, Wang $X$, Ahlquist P. Membrane-shaping host reticulon proteins play crucial roles in viral RNA replication compartment formation and function. Proc Natl Acad Sci U S A a. 2010;107(37):16291-6.

54. Perera R, Riley C, Isaac G, Hopf-Jannasch AS, Moore RJ, Weitz KW, Pasa-Tolic L, Metz TO, Adamec J, Kuhn RJ. Dengue virus infection perturbs lipid homeostasis in infected mosquito cells. PLoS Pathog. 2012;8(3):e1002584

55. Krishnan MN, Sukumaran B, Pal U, Agaisse H, Murray JL, Hodge TW, Fikrig E. Rab 5 is required for the cellular entry of denque and West Nile viruses. J Virol. 2007;81(9):4881-5.

56. Colpitts TM, Moore AC, Kolokoltsov AA, Davey RA. Venezuelan equine encephalitis virus infection of mosquito cells requires acidification as well as mosquito homologs of the endocytic proteins Rab5 and Rab7. Virology. 2007:369(1):78-91.

57. Lee RC, Hapuarachchi HC, Chen KC, Hussain KM, Chen H, Low SL, Ng LC, Lin $\mathrm{R}, \mathrm{Ng} \mathrm{MM}$, Chu JJ. Mosquito cellular factors and functions in mediating the infectious entry of chikungunya virus. PLoS Negl Trop Dis. 2013;7(2):e2050.

58. Drake LL, Boudko DY, Marinotti $O$, Carpenter VK, Dawe AL, Hansen IA. The aquaporin gene family of the yellow fever mosquito, Aedes aegypti. PLoS One. 2010;5(12):e15578.

59. Drake LL, Rodriguez SD, Hansen IA. Functional characterization of aquaporins and aquaglyceroporins of the yellow fever mosquito, Aedes aegypti. Sci Rep. 2015;5:7795.

60. Sanders HR, Evans AM, Ross LS, Gill SS. Blood meal induces global changes in midgut gene expression in the disease vector, Aedes aegypti. Insect Biochem Mol Biol. 2003;33(11):1105-22

61. Evans AM, Aimanova KG, Gill SS. Characterization of a blood-mealresponsive proton-dependent amino acid transporter in the disease vector, Aedes aegypti. J Exp Biol. 2009:212(Pt 20):3263-71.

62. Datan E, Roy SG, Germain G, Zali N, McLean JE, Golshan G, Harbajan S, Lockshin RA, Zakeri Z. Dengue-induced autophagy, virus replication and protection from cell death require ER stress (PERK) pathway activation. Cell Death Dis. 2016:7:e2127.

63. Lee YR, Lei HY, Liu MT, Wang JR, Chen SH, Jiang-Shieh YF, Lin YS, Yeh TM, Liu CC, Liu HS. Autophagic machinery activated by dengue virus enhances virus replication. Virology. 2008;374(2):240-8.

64. Villas-Boas CS, Conceicao TM, Ramirez J, Santoro AB, Da Poian AT, MonteroLomeli M. Dengue virus-induced regulation of the host cell translational machinery. Braz J Med Biol Res. 2009;42(11):1020-6.

65. Sanchez-Vargas I, Scott JC, Poole-Smith BK, Franz AW, Barbosa-Solomieu V, Wilusz J, Olson KE, Blair CD. Dengue virus type 2 infections of Aedes aegypti are modulated by the mosquito's RNA interference pathway. PLoS Pathog. 2009;5(2):e1000299.

66. Erler S, Popp M, Lattorff HM. Dynamics of immune system gene expression upon bacterial challenge and wounding in a social insect (Bombus terrestris). PLoS One. 2011:6(3):e18126.

67. Sanchez-Alvarez M, Montes M, Sanchez-Hernandez N, Hernandez-Munain C, Sune C. Differential effects of sumoylation on transcription and alternative splicing by transcription elongation regulator 1 (TCERG1). J Biol Chem. 2010; 285(20):15220-33.

68. Kerscher O. SUMO junction-what's your function? New insights through SUMO-interacting motifs. EMBO Rep. 2007;8(6):550-5.

69. Vaidyanathan R, Scott TW. Apoptosis in mosquito midgut epithelia associated with West Nile virus infection. Apoptosis. 2006;11(9):1643-51.

70. Walsh D, Mohr I. Viral subversion of the host protein synthesis machinery. Nat Rev Microbiol. 2011;9:860-75.

71. Chang YF, Imam JS, Wilkinson MF. The nonsense-mediated decay RNA surveillance pathway. Annu Rev Biochem. 2007;76:51-74

72. Liu N, Abe M, Sabin LR, Hendriks GJ, Naqvi AS, Yu Z, Cherry S, Bonini NM. The exoribonuclease nibbler controls $3^{\prime}$ end processing of microRNAs in Drosophila. Curr Biol. 2011:21(22):1888-93.

73. Smith DR. An update on mosquito cell expressed dengue virus receptor proteins. Insect Mol Biol. 2012;21(1):1-7.

74. Reyes-del Valle J, Salas-Benito J, Soto-Acosta R, del Angel RM. Dengue virus cellular receptors and tropism. Curr Trop Med Rep. 2014;1(1):36-43.

75. Liu K, Tsujimoto H, Cha SJ, Agre P, Rasgon JL. Aquaporin water channel AgAQP1 in the malaria vector mosquito Anopheles gambiae during blood feeding and humidity adaptation. Proc Natl Acad Sci U S A. 2011;108(15): 6062-6.

76. Chintapalli VR, Wang J, Dow JAT. Using FlyAtlas to identify better Drosophila melanogaster models of human disease. Nat Genet. 2007;39(6):715-20.

77. Heaton NS, Randall G. Multifaceted roles for lipids in viral infection. Trends Microbiol. 2011;19(7):368-75.

78. Courageot MP, Frenkiel MP, Dos Santos CD, Deubel V, Desprès P. Alphaglucosidase inhibitors reduce dengue virus production by affecting the initial steps of virion morphogenesis in the endoplasmic reticulum. J Virol. 2000;74(1):564-72

79. Sayce AC, Alonzi DS, Killingbeck SS, Tyrrell BE, Hill ML, Caputo AT, Iwaki R, Kinami K, Ide D, Kiappes JL, et al. Iminosugars inhibit dengue virus production via inhibition of ER alpha-glucosidases--not glycolipid processing enzymes. PLoS Negl Trop Dis. 2016;10(3):e0004524.

80. Yasunaga A, Hanna SL, Li J, Cho H, Rose PP, Spiridigliozzi A, Gold B, Diamond MS, Cherry S. Genome-wide RNAi screen identifies broadly-acting 
host factors that inhibit arbovirus infection. PLoS Pathog. 2014;10(2): e1003914.

81. Hase T, Summers PL, Eckels KH, Baze WB. An electron and immunoelectron microscopic study of dengue-2 virus infection of cultured mosquito cells: maturation events. Arch Virol. 1987;92(3-4):273-91.

82. Hung YF, Schwarten M, Hoffmann S, Willbold D, Sklan EH, Koenig B. Amino terminal region of dengue virus NS4A cytosolic domain binds to highly curved liposomes. Viruses. 2015;7(7):4119-30

\section{Publisher's Note}

Springer Nature remains neutral with regard to jurisdictional claims in published maps and institutional affiliations.

Ready to submit your research? Choose BMC and benefit from:

- fast, convenient online submission

- thorough peer review by experienced researchers in your field

- rapid publication on acceptance

- support for research data, including large and complex data types

- gold Open Access which fosters wider collaboration and increased citations

- maximum visibility for your research: over $100 \mathrm{M}$ website views per year

At $B M C$, research is always in progress.

Learn more biomedcentral.com/submissions 